DOI https://doi.org/10.18551/rjoas.2018-04.08

\title{
THE ADOPTION LEVEL OF BOKAR PROCESSING AND THE EFFECT TO THE INCREASING FARMERS' INCOME: A CASE STUDY OF RUBBER FARMERS IN KAPUAS REGENCY, CENTRAL KALIMANTAN, INDONESIA
}

\author{
Erlina Yuni \\ Doctoral Program of Agricultural Science, Department of Agricultural Socio-Economic, \\ University of Brawijaya, Malang, Indonesia \\ Syafrial, Koestiono Djoko, Hanani Nuhfil \\ Faculty of Agriculture, Universitas Brawijaya, Malang, Indonesia \\ *E-mail: erlinayuni1968@gmail.com
}

\begin{abstract}
The aim of this study is, first, to analyze the adoption rate of farmers who take the program of bokar (bahan olahan karet rakyat or community's rubber material) processing implemented in the form of Bokar Processing and Marketing Unit (Unit Pengolahan dan Pemasaran Bokar or UPPB) and, the second, to analyze the effect of adoption rate on rubber farmer's income. The method used to determine the sample of this study is disproportionate stratified random sampling method so that a total of 134 families is obtained as respondents. The first objective was analyzed by using descriptive statistics with semantic differential scale. The second research objective was analyzed by multiple regression methods with Statistical Analysis System program (SAS 9.1 for Windows version). The results show that the average farmers' adoption rate is 26,48 among the lowest and maximum score. Therefore, it can be concluded that the adoption rate of the farmers in Kapuas Regency is categorized as moderate or in transition to the implementation of the program. The income from bokar has a significant and positive impact on the adoption rate of the rubber farmers because the UPPB members (farmers) have already adopted the technology that is recommended for bokar processing.
\end{abstract}

\section{KEY WORDS}

Adoption, rubber farmers, bokar bersih program, rubber price, income.

Central Kalimantan is one of the rubber-producing provinces in Indonesia. In 2013, the total area of Public Rubber Plantation, Private Plantation (Perkebunan Besar Swasta or PBS), and State Plantation (Perkebunan Besar Negara or PBN) in Central Kalimantan is 269,700 hectares with a total of production by 227,042 tons. In this case, the Central Kalimantan Provincial Government remains focus to assist the development of community rubber plantation because its existence is very helpful for people's lives. Community rubber plantation is considered not only sustain lives but also create employment opportunities (BPS, 2014).

The government, continuously, have designed good policies at a microeconomic level related to the welfare of the rubber farmers (BPS, 2014) which one of them is the Regulation of the Ministry of Agriculture number 38 of 2008 and the Regulation of the Minister of Trade number 53 of 2009 . The program of rubber quality improvement continues to support rubber farmers to the farmers' income.

The National Program related to the Regulation of the Ministry of Agriculture number 38 of 2008 or known as Bokar Bersih National Movement (Gerakan Nasional Bokar Bersih or GNBB) and the Regulation of the Minister of Trade number 53 of 2009 in Central Kalimantan socialized since 2010/2011. In the realization, the government formed a group of Bokar Processing and Marketing Unit (Unit Pengolahan dan Pemasaran Bokar or UPPB). This program is one of the policy instruments or government efforts to improve the quality of 
rubber (rubber material) so that it can increase the income of rubber farmers through dry bokar processing and as an effort to minimize the risk of rubber prices.

In relation to such matters, farmers are certainly different from each other in receiving innovation or adoption delivered through various programs. It is expected that an acceptance of innovation is not merely a knowledge but to actually implement on farming activities. The acceptance of innovation can be observed directly or indirectly by others as a reflection of changes in attitude, knowledge, and skills (Mardikanto, 1988).

From the description above, this research is important to be done due to the policy from the government through bokar bersih program implemented in the form of Bokar Processing and Marketing Unit (UPPB) especially for the adoption rate of rubber farmers towards the program.

The aim of this study is, first, to analyze the adoption rate of the farmers who take bokar bersih program in bokar processing which is implemented in the form of UPPB and, the second, to analyze the impact of the adoption to the rubber farmers' income.

\section{MATERIALS AND METHODS OF RESEARCH}

The study is focused on Kapuas Regency, Central Kalimantan Province. The location was determined purposively based on the most number of UPPB among the other districts. The method to determine the sample was disproportionate stratified random sampling method. Furthermore, as many as 30\% respondents who are UPPB members and $10 \%$ respondents who are not UPPB members were determined randomly (random sampling). By that, the representatives are expected to represent the population. The total number of farmers are 134 consisting of 63 farmers who are members of UPPB and 71 families who are the non-member of UPPB. The data in this research include primary data and secondary data.

The first objective of this research was assessed by using descriptive statistics with instruments in the form of questionnaires referring to the Regulation of the Ministry of Agriculture number 38 of 2008, the factors affecting bokar quality from latex (Budiman, 2000 ), as well as the supervision record of bokar processing and marketing by the Plantation and Forestry Office of Kapuas Regency in 2015. The measurements were performed by using several items of questions with semantic differential scale (Sugiyono, 2015) based on indicators or questions on adoption variables with three variables (Y) such as bokar processing (Y1), farmer institution (Y2), and bokar marketing (Y3). The differential semantic scale is arranged in a continuum line that has a positive to negative gradation. Then, for the quantitative analysis, the determination used is: (a) a score of 5 for Strongly Agree/Complete/ Appropriate (positive); (b) a score of 4 for Agree/Complete/Appropriate (positive); (c) a score of 3 for Neutral; (d) a score of 2 for Disagree/ Complete/Appropriate (negative); (e) a score of 1 for Strongly Disagree/Complete/Appropriate (negative). Then, the validity and reliability of the research instrument are tested to meet the criteria of validity and reliability.

The measurement techniques are grouped into categories of low, moderate/in transition, and high. The criteria of the farmers' adoption rate are: low if the average score of respondents $\leq$ maximum score; moderate/in transition if the dominant total score is between the lowest score and maximum score; high if the dominant total score of the average score $\geq$ maximum score.

The factors that are suspected to affect the adoption rate of the farmers implemented in the form of UPPB are analyzed by using multiple regression method with SAS (Statistical Analysis System) 9.1 for Windows version with the equation:

$$
\text { ADOPB }=a_{0}+a_{1} \text { HBR }+a_{2} \text { LLK }+a_{3} \text { TIBR }+a_{4} \text { UMR }+a_{5} \text { TPDIKP }+a_{6} \text { LAMKR }+a_{7} \text { JART }+\mu
$$

Hypothesis:

- $\mathrm{H}_{0}: \beta_{i}=0$

- $\mathrm{H}_{\mathrm{a}}: \beta_{i} \neq 0$ 
The criteria for the test are: If $t_{\text {hit }}>t_{t a b}$, then $\mathrm{H}_{0}$ is rejected and $\mathrm{H}_{a}$ is accepted. This means that, partially, the exogenous variable has significant effect on endogenous variable on the $\alpha$, vice versa.

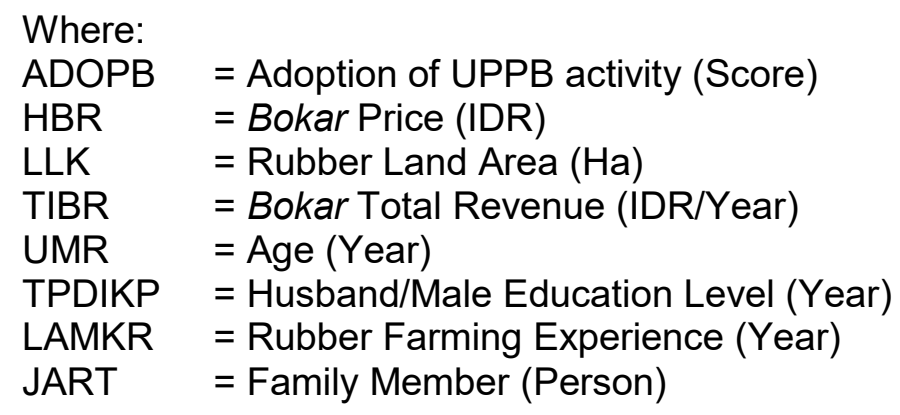

\section{RESULTS AND DISCUSSION}

Adoption of the Rubber Farmers. The development of bokar quality has been issued through the Regulation of the Minister of Agriculture number 38/Permentan/OT.140/8/2008 dated 12 August 2008 concerning Guidelines for Processing and Marketing of Rubber Materials (Bokar) which is followed by the Regulation of the Minister of Trade number 53/ MDAG/PER/10/2009 concerning Supervision of Export Quality of Indonesian Rubber Standard Export Commodity.

To identify the implementation of the program, the adoption of the application level of the farmers to bokar processing can be seen by adjusting and following the guidelines from the Regulation of the Minister of Agriculture number 38 of 2008, the factors that affect the quality of bokar from latex (Budiman, 2000), and the supervision record of bokar processing and marketing conducted by the Plantation and Forestry Office of Kapuas Regency in 2015.

The identification of farmers' adoption rate on bokar processing policy is done through the identification of farmer application on tapping system, tapping equipment and processing facilities, bokar hygiene, water quality, use of freezer, bokar processing, and processing and storage room. If it is generalized, the farmer's adoption rate on bokar processing is presented in Table 1.

Partially, according to Table 1, the results of the research illustrate that the implementation of bokar processing in tapping system (Y1.1), tapping equipment and processing facilities (Y1.2), bokar hygiene (Y1.3), water quality $(\mathrm{Y} 1.4)$, the use of a freezer (Y1.5), and bokar processing (Y1.6) leads to a positive continuum. However, only the existence of bokar processing and storage room (Y1.7) that does not comply the recommendation of total gradation value by $46,03 \%$ which leads to the negative continuum. This is because the temporary storage space provided is not sufficient to accommodate the bokar. Given the limited temporary storage room, some farmers dry their bokar in respective places with para-para made of wood which is less qualified for a storage room. The drying process of the bokar is done by air-dried and should not be exposed to direct sunlight.

Based on Table 1, it can be explained that there are differences in behavior between the members and non-members of UPPB because the non-members are completely untouched by the program and still do the farm conventionally. Nevertheless, some farmers are found to already adopt the recommendations by keeping the bokar hygiene, use freezer, and process the bokar as recommended by UPPB members.

Institutional support for farmers is a unity manifestation factor of individuals who are members of farmer group.

The result of the implementation of farmer institutional policies (Y2) to UPPB organizational structure (Y2.1), the existence of internal quality supervisor (Y2.2), the implementation of the training committee and participants (Y2.4), and activeness in the price information (Y2. 7) is in a positive continuum. 
Table 1 - The Adoption of Respondents towards Bokar Processing Policy

\begin{tabular}{|c|c|c|c|c|c|c|c|}
\hline \multirow{2}{*}{ Number } & & & \multirow{2}{*}{\multicolumn{2}{|c|}{ Indicators }} & & \multicolumn{2}{|c|}{$\begin{array}{c}\text { Score } \\
\text { Percentage }\end{array}$} \\
\hline & & & & & & UPPB & $\begin{array}{l}\text { NON- } \\
\text { UPPB }\end{array}$ \\
\hline 1. & $(\mathrm{Y} 1.1)$ & Tapping System & & $\begin{array}{l}\text { stion (Positive-Negative): } \\
\text { Apply the tapping pattern/flow (Positive). } \\
\text { There is no tapping pattern (Negative). }\end{array}$ & $\begin{array}{l}5 . \\
4 . \\
3 . \\
2 . \\
1 .\end{array}$ & $\begin{array}{c}0,00 \\
46,03 \\
38,10 \\
15,87 \\
0,00\end{array}$ & $\begin{array}{c}0,00 \\
0,00 \\
100,00 \\
0,00 \\
0,00\end{array}$ \\
\hline 2. & $(\mathrm{Y} 1.2)$ & $\begin{array}{l}\text { Tapping equipment } \\
\text { and processing } \\
\text { facilities }\end{array}$ & a) & $\begin{array}{l}\text { Use tapping equipment from clean stainless-steel } \\
\text { materials and clean and sharp tapping knives. } \\
\text { Use simple materials (mineral water bottle, oil/soap } \\
\text { can). }\end{array}$ & $\begin{array}{l}5 . \\
4 . \\
3 . \\
2 . \\
1 .\end{array}$ & $\begin{array}{c}0,00 \\
58,73 \\
30,16 \\
11,11 \\
0,00 \\
\end{array}$ & $\begin{array}{c}0,00 \\
0,00 \\
100,00 \\
0,00 \\
0,00 \\
\end{array}$ \\
\hline 3. & $(\mathrm{Y} 1.3)$ & Bokar Hygiene & a) & $\begin{array}{l}\text { Examine the dirt that comes from twigs, skin, leaves, } \\
\text { etc. as directed. } \\
\text { Left to dry. }\end{array}$ & $\begin{array}{l}5 . \\
4 . \\
3 . \\
2 . \\
1 .\end{array}$ & $\begin{array}{c}0,00 \\
47,62 \\
38,10 \\
14,29 \\
0,00\end{array}$ & $\begin{array}{c}0,00 \\
9,52 \\
90,48 \\
0,00 \\
0,00\end{array}$ \\
\hline 4. & $(\mathrm{Y} 1.4)$ & Water quality & $\begin{array}{l}\text { a) } \\
\text { b) }\end{array}$ & $\begin{array}{l}\text { Clean water. } \\
\text { Water ditches. }\end{array}$ & $\begin{array}{l}5 . \\
4 . \\
3 . \\
2 . \\
1 .\end{array}$ & $\begin{array}{c}17,46 \\
77,78 \\
4,76 \\
0,00 \\
0,00 \\
\end{array}$ & $\begin{array}{c}0,00 \\
0,00 \\
100,00 \\
0,00 \\
0,00 \\
\end{array}$ \\
\hline 5. & $(\mathrm{Y} 1.5)$ & Freezing materials & a) & $\begin{array}{l}\text { Use freezing materials from Ant Acids / Sintas / } \\
\text { Specta / Durap, etc. as recommended. } \\
\text { Traditional freezing materials as tawas, umbi } \\
\text { gadung, umbi hutan. }\end{array}$ & $\begin{array}{l}5 . \\
4 . \\
3 . \\
2 . \\
1 .\end{array}$ & $\begin{array}{c}0,00 \\
53,97 \\
39,68 \\
6,35 \\
0,00 \\
\end{array}$ & $\begin{array}{c}0,00 \\
34,92 \\
63,49 \\
1,59 \\
0,00 \\
\end{array}$ \\
\hline 6. & $(\mathrm{Y} 1.6)$ & Bokar processing & & $\begin{array}{l}\text { Bokar is dried according to the product types } \\
\text { (Sheet/lump). } \\
\text { soaked. }\end{array}$ & $\begin{array}{l}5 . \\
4 . \\
3 . \\
2 . \\
1 .\end{array}$ & $\begin{array}{c}36,51 \\
61,90 \\
1,59 \\
0,00 \\
0,00 \\
\end{array}$ & $\begin{array}{c}0,00 \\
34,92 \\
63,49 \\
1,59 \\
0,00\end{array}$ \\
\hline 7. & $(\mathrm{Y} 1.7)$ & $\begin{array}{l}\text { Processing and } \\
\text { Storage Room }\end{array}$ & a) & $\begin{array}{l}\text { Bokar processing and storage room is qualified as } \\
\text { the recommendation (no water leak, good air } \\
\text { circulation, non-leaking roof, and no direct sunlight). } \\
\text { Not qualified. }\end{array}$ & $\begin{array}{l}5 . \\
4 . \\
3 . \\
2 . \\
1 .\end{array}$ & $\begin{array}{c}0,00 \\
38,10 \\
15,87 \\
46,03 \\
0,00 \\
\end{array}$ & $\begin{array}{c}0,00 \\
0,00 \\
100,00 \\
0,00 \\
0,00 \\
\end{array}$ \\
\hline
\end{tabular}

However, the farmers' knowledge relating to the existence of SOP of tapping, processing, and storage of bokar (Y2.3), bokar collection (Y2.5), and participation in bokar drying (Y2.6) leads to a negative continuum. This means that the institutional activity on the component is still not as expected.

The identification of the farmers' adoption rate on bokar marketing policy is done by identifying the application of farmers' knowledge to the components of bokar purchasing and marketing activities and partnership with buyers in relation to transportation costs and the sharing of sales proceeds.

Partially, the research results of bokar marketing policy (Y3) on farmer's purchasing and marketing adoption to the knowledge and existence of purchase records (Y3.1.a), product stock records (Y3.1.b), payments to member records (Y3.1.e), the knowledge of the relationship with the buyer (Y3.2), knowledge and agreement on transportation costs (Y3.3), as well as knowledge on the revenue share (Y3.4) show a positive continuum. However, the knowledge of the required technical shipment (Y3.1.c), the knowledge of sales records including the quality of sold products (Y3.1.d) has a negative continuum. This means that the institutional activity still run not as expected.

Based on Table 4, the highest adoption rate is 30,67 and the lowest score is 21,67 . Meanwhile, the average score of the farmers is 26,48 which in between the lowest and highest score. It can be concluded that the adoption rate of farmers in Kapuas Regency is moderate or in the transition towards the implementation of the program and technological improvement. The activities conducted by farmers in Kapuas Regency need to be improved so that the implementation of the program can actually be felt by farmers in the farming activities. 
RJOAS, 4(76), April 2018

Table 2 - The Adoption of Respondents towards Farmers Institutional Policy

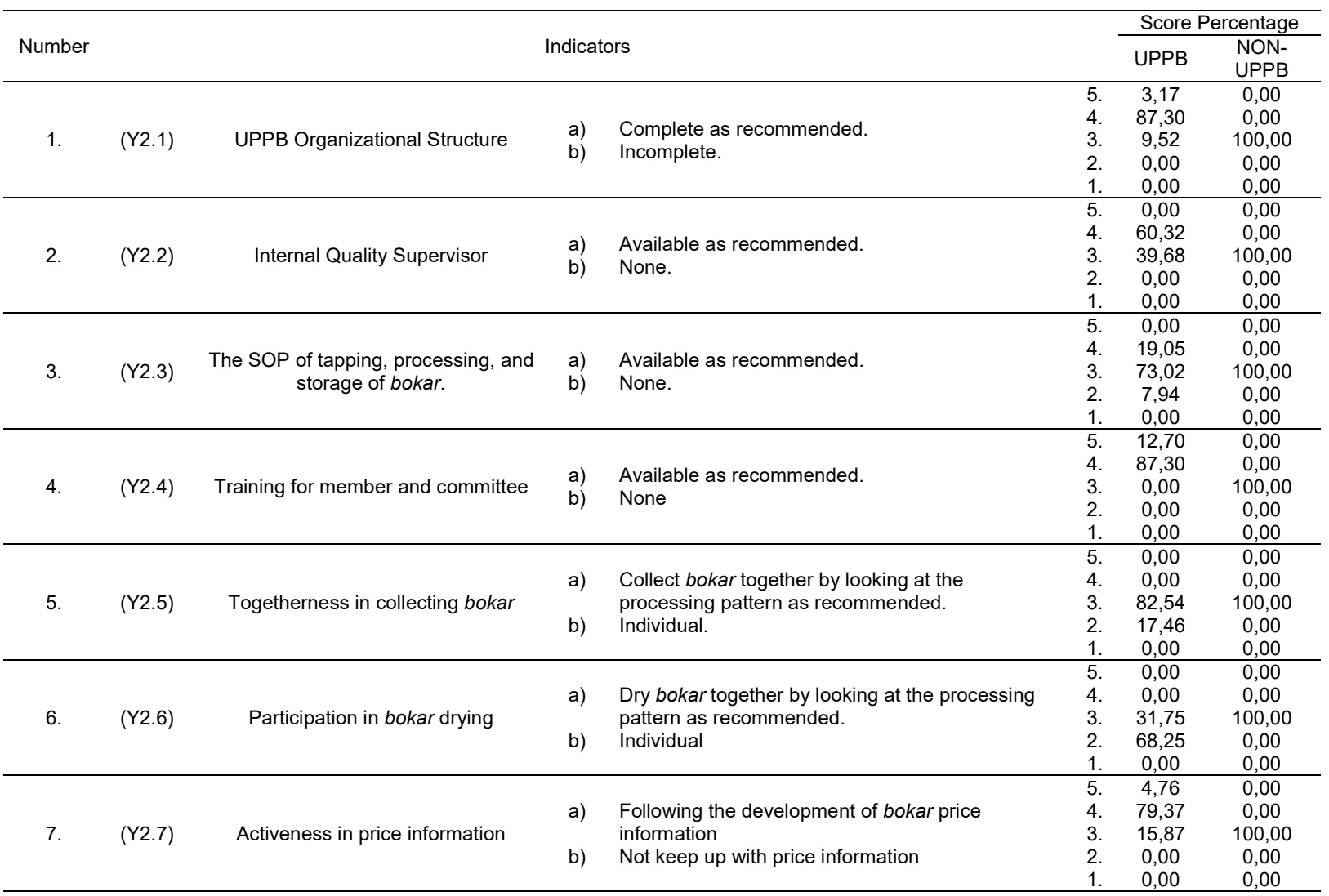

Table 3 - The Adoption of Respondents towards Bokar Marketing Policy

\begin{tabular}{|c|c|c|c|c|c|c|c|}
\hline \multirow[b]{2}{*}{ Number } & & & \multirow{2}{*}{\multicolumn{2}{|c|}{ Indicators }} & & \multicolumn{2}{|c|}{ Score Percentage } \\
\hline & & & & & & UPPB & $\begin{array}{l}\text { NON- } \\
\text { UPPB }\end{array}$ \\
\hline 1. & (Y3.1.a) & $\begin{array}{l}\text { Purchasing and } \\
\text { Marketing }\end{array}$ & $\begin{array}{l}\text { a) } \\
\text { b) }\end{array}$ & $\begin{array}{l}\text { There is purchase record of each farmer } \\
\text { No record }\end{array}$ & $\begin{array}{l}5 . \\
4 . \\
3 . \\
2 . \\
1 .\end{array}$ & $\begin{array}{c}0,00 \\
76,19 \\
20,63 \\
3,17 \\
0,00\end{array}$ & $\begin{array}{c}0,00 \\
0,00 \\
100,00 \\
0,00 \\
0,00\end{array}$ \\
\hline 2. & (Y3.1.b) & & $\begin{array}{l}\text { a) } \\
\text { b) }\end{array}$ & $\begin{array}{l}\text { There is a record of product stocks } \\
\text { No record }\end{array}$ & $\begin{array}{l}5 . \\
4 . \\
3 . \\
2 . \\
1 .\end{array}$ & $\begin{array}{c}0,00 \\
55,56 \\
41,27 \\
3,17 \\
0,00\end{array}$ & $\begin{array}{c}0,00 \\
0,00 \\
100,00 \\
0,00 \\
0,00\end{array}$ \\
\hline 3. & (Y3.1.c) & & $\begin{array}{l}\text { a) } \\
\text { b) }\end{array}$ & $\begin{array}{l}\text { There is a required technical shipment } \\
\text { No requirements }\end{array}$ & $\begin{array}{l}5 . \\
4 . \\
3 . \\
2 . \\
1 .\end{array}$ & $\begin{array}{c}0,00 \\
30,16 \\
69,84 \\
0,00 \\
0,00\end{array}$ & $\begin{array}{c}0,00 \\
0,00 \\
100,00 \\
0,00 \\
0,00\end{array}$ \\
\hline 4. & (Y3.1.d) & & $\begin{array}{l}\text { a) } \\
\text { b) }\end{array}$ & $\begin{array}{l}\text { There is sales record including the quality of sold products } \\
\text { No record }\end{array}$ & $\begin{array}{l}5 . \\
4 . \\
3 . \\
2 . \\
1 .\end{array}$ & $\begin{array}{c}0,00 \\
44,44 \\
55,56 \\
0,00 \\
0,00 \\
\end{array}$ & $\begin{array}{c}0,00 \\
0,00 \\
100,00 \\
0,00 \\
0,00 \\
\end{array}$ \\
\hline 5. & (Y3.1.e) & & $\begin{array}{l}\text { a) } \\
\text { b) }\end{array}$ & $\begin{array}{l}\text { There is a payment record to the member } \\
\text { No record }\end{array}$ & $\begin{array}{l}5 . \\
4 . \\
3 . \\
2 . \\
1 .\end{array}$ & $\begin{array}{c}0,00 \\
85,71 \\
14,29 \\
0,00 \\
0,00\end{array}$ & $\begin{array}{c}0,00 \\
0,00 \\
100,00 \\
0,00 \\
0,00\end{array}$ \\
\hline 6. & (Y3.2) & $\begin{array}{l}\text { Partnership with } \\
\text { customers }\end{array}$ & $\begin{array}{l}\text { a) } \\
\text { b) }\end{array}$ & $\begin{array}{l}\text { There is a partnership with factory } \\
\text { No partnership }\end{array}$ & $\begin{array}{l}5 . \\
4 . \\
3 . \\
2 . \\
1 .\end{array}$ & $\begin{array}{c}6,35 \\
85,71 \\
7,94 \\
0,00 \\
0,00 \\
\end{array}$ & $\begin{array}{c}0,00 \\
0,00 \\
100,00 \\
0,00 \\
0,00 \\
\end{array}$ \\
\hline 7. & (Y3.3) & Transportation cost & $\begin{array}{l}\text { a) } \\
\text { b) }\end{array}$ & $\begin{array}{l}\text { There is an agreement on the cost of transportation and the } \\
\text { wage of unloading workers. } \\
\text { No agreement. }\end{array}$ & $\begin{array}{l}5 . \\
4 . \\
3 . \\
2 . \\
1 .\end{array}$ & $\begin{array}{c}0,00 \\
85,71 \\
6,35 \\
7,94 \\
0,00\end{array}$ & $\begin{array}{c}0,00 \\
0,00 \\
100,00 \\
0,00 \\
0,00\end{array}$ \\
\hline 8. & (Y3.4) & Sales revenue sharing & $\begin{array}{l}\text { a) } \\
\text { b) }\end{array}$ & $\begin{array}{l}\text { Agree with the revenue sharing for transportation costs and } \\
\text { wage of unloading workers. } \\
\text { Disagree. }\end{array}$ & $\begin{array}{l}5 . \\
4 . \\
3 . \\
2 . \\
1 .\end{array}$ & $\begin{array}{c}0,00 \\
73,02 \\
17,46 \\
9,52 \\
0,00\end{array}$ & $\begin{array}{c}0,00 \\
0,00 \\
100,00 \\
0,00 \\
0,00\end{array}$ \\
\hline
\end{tabular}


Table 4 - Highest and Lowest Adoption Rate of Rubber Farmers in Kapuas Regency, Central Kalimantan

\begin{tabular}{cccc}
\hline \multirow{2}{*}{ Number } & \multirow{2}{*}{ Variables } & \multicolumn{2}{c}{ Total Score } \\
\cline { 3 - 4 } & Bokar Processing (Y1) & Highest & Lowest \\
\hline 1. & Farmers Institutional Level (Y2) & 31 & 22 \\
2. & Bokar Marketing(Y3) & 28 & 21 \\
3. & Total & 33 & 22 \\
\hline & Average & 92 & 65 \\
\hline
\end{tabular}

Source: Result of Primary Data Analysis, 2017ю

Analysis of Cost, Income, and Revenue of Bokarю The cost, income, and revenue earned by farmers from rubber farming activities in one year of the production process are presented in the form of a farming system, which can be seen in Table 5.

Based on the performance of farming in Table 5, it can be concluded that there is a large difference of income between farmers of UPPB members and non-UPPB members. This happens due to the difference in the price of higher valued products based on the shape and quality of the products. The UPPB members obtained IDR 12,968,128,39/hectares every year while the non-members obtained IDR $8,814,397,90 /$ hectares every year. The results of input-output analysis on UPPB members obtained a value that is equal to 1,62 . This means that every rupiah inculcated by the members of UPPB will generate income equal to 1,62 rupiah. This result is bigger than the output of the non-members. The benefit-cost ratio shows a value of 5,27 which means that every rupiah of a capital increase of UPPB members will get an additional value of 5,27 rupiah.

Table 5 - Farming activity, Average Cost, Income and Revenue of Bokar in Kapuas Regency

\begin{tabular}{|c|c|c|c|}
\hline \multirow{2}{*}{ Number } & \multirow{2}{*}{ Description } & \multicolumn{2}{|c|}{ Rubber Farming } \\
\hline & & UPPB & Non-UPPB \\
\hline 1. & Output Price of Bokar at Farmer Level (IDR/Kg) & $6463-7100$ & $4100-6000$ \\
\hline \multirow{7}{*}{2.} & Explicit Cost: & & \\
\hline & a. Urea fertilizer (IDR) & $158.538,46$ & $126.256,25$ \\
\hline & b. NPK fertilizer (IDR) & $156.027,03$ & $166.870,50$ \\
\hline & c. Decline of Tapping Tool Value (IDR) & $170.362,99$ & $160.786,68$ \\
\hline & d. Use of Freezing Material (IDR) & $253.733,77$ & $187.380,99$ \\
\hline & e. Marketing Cost (IDR) & $281.974,62$ & $230.226,81$ \\
\hline & Total Explicit Cost (IDR) & 1.020.636,87 & $871.521,23$ \\
\hline \multirow{4}{*}{3.} & Implicit Cost: & & \\
\hline & a. Male Workers (IDR) & $5.409 .639,13$ & $5.057 .503,17$ \\
\hline & b. Female Workers (IDR) & 2.204 .095 .81 & $1.889 .000,89$ \\
\hline & Total Implicit Cost (IDR) & 7.613.734,94 & $6.946 .504,06$ \\
\hline 4. & Total Cost (3 and 4) (IDR) & $8.634 .371,81$ & $7.818 .025,29$ \\
\hline \multirow{3}{*}{5.} & Production $(\mathrm{Kg})$ : & & \\
\hline & a. Male & 1693,04 & 1387,03 \\
\hline & b. Female & 686,12 & 633,84 \\
\hline 6. & Income (IDR) & 13.988.765,26 & $9.685 .919,13$ \\
\hline 7. & Revenue (IDR) & $12.968 .128,39$ & $8.814 .397,90$ \\
\hline 8. & Output Input Ratio & 1,62 & 1,24 \\
\hline 9. & B/C Ratio & 5,27 & \\
\hline
\end{tabular}

Source: Result of Primary Data Analysis, 2017.

The Effect of Adoption Rate on Farmers Income. In this research, the analysis is performed with Statistical Analysis System Program (SAS) based on the influence of rubber farmers' adoption rate (ADOPB) on the characteristics related to farming factors such as bokar price (HBR), rubber area (LLK), total revenues of bokar (TIBR), husband age (UMR), husband education level (TPDIKP), farming experience (LAMKR), number of household members (JART), and membership status at UPPB (STAGOT). The discussion that is in accordance with the objectives of the research is the effect of the adoption variable and the 
income of the farmers with the assumption that other factors besides the income variable are ceteris paribus. The more detailed data are presented in Table 6 below.

Table 6 - The Results of Equation Parameter Estimation of Adoption Level and the Factors of Farming and Rubber Farmers Characteristics

\begin{tabular}{cccccc}
\hline $\begin{array}{c}\text { Dependent } \\
\text { Variable }\end{array}$ & $\begin{array}{c}\text { Independent } \\
\text { Variable }\end{array}$ & $\begin{array}{c}\text { Parameter } \\
\text { Value }\end{array}$ & t-count & Significance Level & DW \\
\hline & Intercept & 66.59279 & 8.39 & $<.0001$ & \\
& HBR & 0.04451 & 2.10 & 0.0294 & \\
& LLK & 5.12573 & 2.54 & 0.0003 & \\
ADOPB & TIBR & $1.389 \mathrm{E}-6$ & 2.74 & 0.0070 & 1.713735 \\
& UMR & 0.21070 & 2.39 & 0.0095 & \\
& TPDIKP & 0.272830 & 1.38 & 0.1711 & \\
& LAMKR & -0.082089 & -0.84 & 0.0244 & \\
& JART & -0.04428 & -0.09 & 0.9255 & \\
& STAGOT & 12.16977 & 8.46 & $<.0001$ & \\
\hline
\end{tabular}

Source: Result of Primary Data Analysis, 2017.

The results of the coefficient of determination $\left(R^{2}\right)$ is used to determine the accuracy of the model used in the percentage of dependent variables which can be explained by the independent variables. From the analysis, the value of the coefficient of determination $\left(R^{2}\right)$ is 0,77954 meaning that $77,954 \%$ variation of adoption variable (dependent variables) can be explained by the variables in the model (independent variable) while the rest of $22,046 \%$ will be explained by other variables outside the model.

F-test is used to determine the effect of all independent variables on the dependent variables. Based on the F-count analysis, the F-test is known to be 54,81 . This value is greater with a significance level that is less than one percent. This means that the independent variables included in the equation affect the dependent variables.

The result of autocorrelation test with Durbin Watson (DW) criterion test shows a number of 1,713735 which is between 1,55 and 2,46 (Misbahuddin and Hasan, 2013). This can be said that there is no autocorrelation in the structural equation.

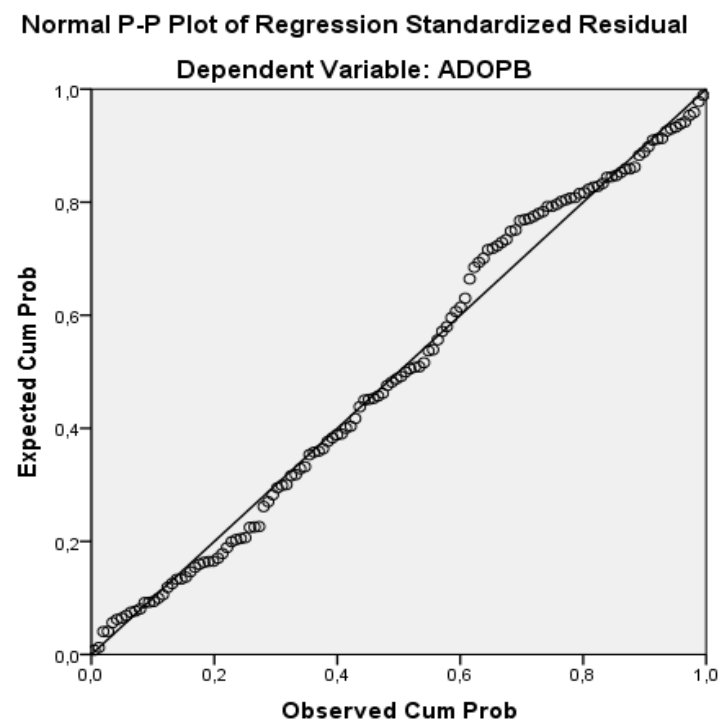

Figure 1 - Distribution of P-P plot

Furthermore, the t-test is used to know the influence of independent variables partially to dependent variables. Based on Table 6 , it can be seen that the value of t-arithmetic in the variable of bokar revenue (TIBR) is 2,74 . This gives a significant effect on the level of 
application or adoption where the effect is positive and significant at the error rate of five percent. Therefore, based on the partial analysis of the adoption equation, the variable of bokar revenue affects the adoption variable. This happens because the UPPB members who have adopted the suggested technology in bokar processing already in transition to technological improvements even though all the recommended components not really been adopted by the farmers. Moreover, this happens because they need to increase the activity of the group. The normal distribution of P-P plot from the regression of adoption variables to the factors affecting the adoption rate can be seen in Figure 1.

In Fig. 1, the adoption rate of rubber farmers can be said to be normally distributed. This can be seen from the distribution of data that spread around the diagonal line and follow the direction of the diagonal line.

\section{CONCLUSION}

The adoption rate of the farmers who followed the bokar bersih program in bokar processing which is implemented in the form of Bokar Processing and Marketing Unit (UPPB) is classified in the category of moderate/in transition to the implementation of the program although it still needs more improvements. This program is very beneficial for farmers as one of the efforts to improve technology as well as farmers' income. This is done to stimulate farmers who are the members of the UPPB towards the efforts to improve farming and to create better and sustainable bokar processing.

The adoption rate has an effect on the increase of farmers' income which can be seen from the coefficient of determination value $\left(R^{2}\right)$ that is equal to 0,77954 which means that $77,954 \%$ variation of the adoption variable (dependent variables) can be explained by the variables in the model (independent variable) and the rest $22,046 \%$ will be explained by another variable outside the model.

The result of F-test analysis shows a number of 54,81 with an error rate that is less than one percent. The partial influence of independent variable to dependent variable is examined by using t-test. Based on the result of the analysis, it can be seen that bokar revenue has a significant effect on the adoption rate of rubber farmers where the effect is positive and significant at the error rate of five percent. By that, based on the partial analysis of the adoption equation, the variable of bokar revenue affects the adoption variable. This is because UPPB farmers who have adopted the recommended technology on bokar processing have been in transition to technological improvements although all recommended components have not really been adopted by farmers. This also happens because the farmers want to increase their group activities.

\section{RECOMMENDATIONS}

The improvement of bokar cultivation and processing facilities is very needed for rubber farmers in Kapuas Regency. The efforts to increase the income of rubber farmers need to be supported by the use of adequate facilities at the level of bokar cultivation and processing because adequate facility and infrastructure are one of the compliments both in production and processing level. By that, it is expected to increase latex productivity and bokar processing productivity.

It is essential to have institutional strengthening at the farmers level, especially for young farmers through various non-formal education in the form of skills related to the development of rubber processing business. The development of product competitiveness at the local level through established economic organizations is intended to increase the income and welfare of rubber farmers.

In consideration that the marketing in the research location is part of the effort that influences the rubber farmers, it is necessary to improve the road infrastructure and transportation in order to support the transportation from and to the factory or final sales location. 


\section{REFERENCES}

1. Badan Litbang Pertanian, 2013. Prospek dan Arah Pengembangan Agribisnis Karet. Jakarta.

2. Badan Pusat Statistik, 2014. Kalimantan Tengah Dalam Angka 2013. Provinsi Kalimantan Tengah.

3. Badan Pusat Statistik, 2016. Provinsi Kalimantan Tengah Dalam Angka 2015. Provinsi Kalimantan Tengah.

4. Badan Pusat Statistik, 2016. Kabupaten Kapuas Dalam Angka 2015. Provinsi Kalimantan Tengah.

5. Budiman A., 2000. The Future of Natural Rubber Production and Quality in Indonesia. http://digilib.unila.ac.id. diakses 10-11-2014.

Ditjen Pengolahan dan Pemasaran Hasil Pertanian, 2011. Pedoman Penerapan Sistem Jaminan Mutu Bokar. Kementerian Pertanian. Jakarta.

6. Effiong J.B., and Effiong G. B., 2014. Adoption of Improved Rubber Production Technologies By Farmers In Akwa Ibom State, Nigeria. Global Journal Of Agricultural Sciences Vol.14.

7. Ethridge Don, 1995. Research Methodology In Applied Economics (And Conducting Economic Research). lowa State University Press. Pp: 101-113

8. Goswami, S.H., and Challa, O., 2007. Economic Analysis of Smallholder Rubber Plantations in West Garo Hills District of Meghalaya. Indian Journal of Agricultural Economics; Oct-Des 2007; 62, 4; ProQuest.

9. Hailu B.S., Abrha B. K., and Weldegiorgis K. A., 2014. Adoption and Impact of Agricultural Tecnologies on Farm Income: Evidence From Southern Tigray, Northern Ethiopia. International Journal of Foodand Agricultural Economics. ISSN 2147-8988. Vol. 2 No.4, (2014). Pages 91-94.

10. Huda N., Suharjo B., Suryani A., 2013. Adopsi Teknologi Budi Daya dan Strategi Pengembangan Perkebunan Karet Rakyat di Kecamatan Teweh Tengah Kabupaten Barito Utara. Journal Manajemen IKM, ISSN 2085-8418. Institut Pertanian Bogor.

11. International Rubber Study Group (2007). The Rubber Industry of Indonesia: Review and Prospect to 2020. International Rubber Study Group.

12. Ling Hsu Wan, 1997. Technology Adoption, Risk, and Intrafamily Time Allocation: An Application of The Agricultural Household Model. Thesis. Doctor of Philosophy. Agricultural Economics. The Pennsylvania State University. Departement of Agricultural Economics and Rural Sociologi.

13. Mardikanto T., 1988. Komunikasi Pembangunan. UNS Press Surakarta.

14. Maspanger, D., dan Honggokusumo, S. 2004. Dampak Penerapan Produksi Bersih Industri Crumb Rubber Pada Peningkatan Pasar Global. Disampaikan pada Seminar/Temu Usaha Sosialisasi Produksi Bersih Industri Crumb Rubber. Pekan Baru, 6 Oktober 2004.

15. Misbahuddin dan Hasan, I., 2013. Analisis Data Penelitian dengan Statistik. Edisi ke-2. Bumi Aksara. Jakarta. Hal.71-166; 258-267.

16. Mubyarto dan Dewanta A., 1991. Karet, Kajian Sosial-Ekonomi. Penerbit Aditya Media. Yogyakarta.

17. Rajasekharan P., and Veraputhran, 2001. Adoption of Intercropping in Rubber Smallholding in Kerala, India: A Tobit Analysis. Rubber Research Institude of India, Kottayam India.

18. Rogers, E.M., and F. Shoemaker, 1971. Communication of Innovation: A Cross Cultural Approach. The Free Press. New York.

19. Rogers, E.M., 1995. Diffusion of Innovations. Cetakan ke-4. New York: Free Press.

20. Setyamidjaja D., 1993. Karet, Budidaya dan Pengolahan. Penerbit Kanisius. Yogyakarta.

21. Sitepu K. Rasidin., dan Sinaga M. Bonar., 2006. Aplikasi Model Ekonometrika: Estimasi, Simulasi dan Peramalan Menggunakan SAS. Program Studi IImu Ekonomi Pertanian. Sekolah Pascasarjana. Institut Pertanian Bogor. Bogor. Hal.450. 
22. Sugiyono, 2015. Metode Penelitian Kuantitatif Kualitatif dan R \& D. Penerbit Alfabeta. Bandung. Hal.205-269.

23. Summer, D. A., 1982. The Off-Farm Labor Supply of Farmers. American Journal of Agricultural Economics. Vol. 64, pp. 499-509.

24. Ugwa, I. K., and Abubakar, M., 2006. Evaluation of The Adoption of Improved Rubber Farmers in Mid-Western Nigeria. Journal of Sustainable Tropical Agricultural Resources. Nigeria.

25. Utomo, T.P., A.M. Fauzi, T. Tedja, M. Romli, A. Aman, dan S. Honggokusumo. 2008. Kajian Perbaikan Agroindustri Karet Remah Menggunakan Interpretative Structural Modelling. Prosiding Seminar Nasional Sains dan Teknologi-II 2008. Bandar Lampung, 17-18 November 2008.

26. Widarjono Agus., 2007. Ekonometrika: Teori dan Aplikasi. Penerbit Ekonisia. Yogyakarta. Hal.63-169; 267-283. 